Ключевые слова: инновационная культура, развитие инновационной культуры, руководитель учреждения общего среднего образования, магистратура, магистерская подготовка.

\title{
SUMMARY
}

Kurok Vira. Theoretical and methodological foundations of innovative culture development of the future manager of the general secondary education institution in the master's training process.

The article describes the basic theoretical and methodological measures of innovative culture development of the future manager of the general secondary education institution. The content of the basic concepts of principles and approaches to forming the culture of the manager is determined, the necessity of purposeful preparation of the future manager of the general secondary education institution for innovative activity of a manager is substantiated. The manager's willingness to innovate is determined by the important professional quality. The innovative culture of the manager of the general secondary education institution is considered as an integral part of his general culture, which is an integrative characteristic of a specialist and includes personal innovative potential formed during the implementation of social and educational innovations, style of management activity and manager's readiness to introduce new methods, content organization and management of the educational process. The manager's innovative culture ensures the readiness to generate and implement new ideas, the ability to support and implement innovative learning technologies in the educational process, the ability to implement modern management mechanisms in modern education.

The readiness of the manager of the general secondary education institution to introduce innovative activity is provision of quality educational service that meets the modern requirements for the future specialists' training. He is a professional in his field, who is creative in solving a particular problem or achieving a specific result. Of course, modernization of the education sector is not possible without innovative managers who are in line with the government's intended educational development strategy. While studying an innovative management culture in education, one should base him/herself on the following principles: scientific, systematic, humanism, professionalism.

It is stated that innovative culture of the manager of the general secondary education institution is connected with his/her innovative and creative thinking, is the basis of his/her self-realization and at the same time undergoes transformation due to the influence of creative thinking. Modern researchers distinguish the following components of the manager's innovative culture of the general secondary education institution: cognitive, motivational, creative, subject-activity.

Key words: innovative culture, development of innovative culture, manager of the general secondary education institution, master's degree, master's training.

удк 378: 811.14

Олеся Лазер-Паньків

Київський національний університет імені Тараса Шевченка ORCID ID 0000-0001-5281-5816

DOI 10.24139/2312-5993/2020.02/121-135

\section{ЧИННИКИ ПІДВИЩЕННЯ НАВЧАЛЬНОÏ МОТИВАЦІЇ У ПРОЦЕСІ ФОРМУВАННЯ ЛІНГВОСОЦІОКУЛЬТУРНОЇ КОМПЕТЕНТНОСТІ 3 ДАВНЬОГРЕЦЬКОЇ МОВИ}

Статтю присвячено аналізу чинників підвищення навчальної мотивації у процесі формування лінгвосоціокультурної компетентності з давньогрецької мови. 
Окреслюються, зокрема, особливості сучасної освітньої парадигми та місце в ній давньогрецької мови; особливості організації прочесу навчання давньогрецької мови, шляхи та методи підвищення якості ї викладання; найважливіші особливості суб'єктів навчальної діяльності, від яких залежить рівень мотивації вивчення давньогрецької мови; специфіка давньогрецької мови та міра складності оволодіння нею як чинники можливого негативного впливу на мотивацію; важливість давньогрецької мови для професійної підготовки студентів. Визначаються можливості використання процесу формування лінгвосоціокультурної компетентності як засобу підвищення мотивації до вивчення давньогрецької мови крізь призму кожного із зазначених чинників.

Ключові слова: навчальна мотивація, лінгвосочіокультурна компетентність, давньогрецька мова, сучасна освітня парадигма, суб'єкти навчальної діяльності.

\section{Постановка проблеми та аналіз актуальних досліджень.} Запровадження в українській освітній парадигмі компетентнісного підходу внаслідок приєднання України до Болонського процесу та перехід на кредитно-модульну систему навчання 3 «переорієнтацію 3 процесу на результат освіти в діяльнісному вимірі» (Методика, 2013, с. 84) зумовили актуалізацію інтересу до навчальної мотивації. Мотивація $\epsilon$ рушієм навчально-пізнавальної діяльності людини (Гуревич, 2008, с. 380), адже визначає «ступінь інтегрованості людини в діяльність» (Варданян, 1998, с. 45) та ступінь їі ефективності. Як справедливо зазначає М. Варій, «що вищий рівень мотивації, то більше чинників (мотивів) спонукають людину до діяльності, то більше зусиль вона схильна докладати» (Варій, 2007, с. 646), відповідно, і результат діяльності буде вищим. Доведено, зокрема, що трудова віддача немотивованих людей становить лише 20 \% трудової віддачі працівників, яких стимулюють (Управлінські, 2004); за іншими даними, «із запровадженням мотивації продуктивність знаходження рішень зростає у 3,5 рази» (Столяренко, 2012). Натомість, відсутність мотивації та стимулів визначається як одна з головних причин зниження якості підготовки студентів.

Дослідники наголошують, що «формування мотивації - тривалий процес, пов'язаний зі становленням особистості в цілому» (Маркова, 1990, с. 45), причому швидкість та якість розвитку навчальної мотивації не $\epsilon$ сталою величиною, вона «залежить від співвідношення системи цінностей особистості й системи цінностей суспільства, до якого ця особистість належить» (Єрохін, с. 20-27). Ієрархія та взаємодія мотивів, які складають навчальну мотивацію, постійно змінюється під впливом низки умов та факторів.

Окреслення чинників підвищення рівня мотивації вивчення іноземної мови набуває в сучасній лінгводидактиці особливої актуальності, відповідно, стало об'єктом прицільної уваги в багатьох наукових працях. Значний внесок у вирішення зазначеної проблеми було зроблено свого часу Н. Арістовою, О. Бутирською, В. Ґарднером, І. Зимньою, Н. Ємельяновою, Є. Каргіною,
Н. Касаткіною,
Г. Копил,
В. Леонтьєвим,
О. Мельохіною,
В. Тимошенко, 
Н. Салановичем, Н. Симоновою, О. Хрипком, О. Яцишиним та ін., роботи яких становлять методологічну базу нашого дослідження.

У сучасній методичній науці вже аксіоматичним є твердження про те, що процес навчання іноземної мови можливий лише синкретично 3 навчанням іноземної культури. За О. Тарнопольським (Тарнопольський, 2019, с. 108), соціокультурна компетентність $€$ «домінувальною порівняно 3 компетентністю лінгвістичною. Саме вміння, що входять до соціолінгвістичної компетентності, 'запускають' ті комплекси вимовних, граматичних та лексичних автоматизмів і навичок, які $€$ найбільш прийнятними в кожному конкретному випадку мовленнєвого спілкування, тобто саме вони 'керують' тими навичками, що задіяні в комунікації». До того ж, прагнення познайомитися з особливостями країни мови, що вивчається, з ментальністю носіїв мови (тобто, лінгвосоціокультурний компонент змісту навчання іноземної мови), визначається як один із найважливіших мотиваційних стимулів, ефективний засіб підвищення рівня мотивації студентів до вивчення іноземної мови. Необхідність співвивчення мови і культури у процесі навчання класичних мов втілюється як у методичних розробках, так і в практиці їх викладання. Так, у Standards for Classical Language Learning (Standards, 1997; Standards, 2017) сформульовано принцип п'яти «С», який має застосовуватися у процесі навчання класичних мов: Communication (комунікація), Culture (культура), Connections (зв'язки), Comparisons (порівняння) та Communities (спільноти). Опанування базовими засобами для читання оригінальних текстів та поглиблення знань з античної культури визначаються як пріоритетні цілі викладання початкового курсу давньогрецької мови (ДМ) на класичних відділеннях 24 університетів Великої Британії, про що свідчать, зокрема, результати опитування, проведеного М. Лойд (M. Lloyd) та Дж. Робсоном (J. Robson) у 2013 р. та оприлюдненого у 2018 р. (A Survey, 2018).

Метою пропонованого дослідження $€$ аналіз найважливіших чинників, які впливають на навчальну мотивацію студентів у процесі вивчення ДМ, та можливості використання процесу формування лінгвосоціокультурної компетентності (ЛСКК) як засобу підвищення рівня навчальної мотивації, що є особливо актуальним стосовно класичних мов (давньогрецької та латини), які не використовуються як мови живого спілкування, однак не зазнало детального та всебічного висвітлення в наукових працях.

Методи дослідження. Для досягнення означеної мети було використано комплекс теоретичних та емпіричних методів дослідження: критичний аналіз, узагальнення й систематизація вітчизняної та зарубіжної наукової літератури з методики навчання іноземних мов, психології, лінгвістики, педагогіки, культурології для узагальнення теоретичних даних із досліджуваної проблеми, аналіз чинних програм для закладів вищої освіти та нормативних документів щодо впровадження різних підходів у 
процес навчання іноземної мови, вивчення та узагальнення теоретичного досвіду формування мотивації у процесі навчання іноземної мови; наукове педагогічне спостереження за процесом навчання.

Виклад основного матеріалу. Незважаючи на значний інтерес, який викликає питання формування навчальної мотивації, у сучасних психологопедагогічних студіях не існує єдиного універсального визначення цього поняття. Спираючись на дослідження Н. Арістової, В. Вілюнаса, І. Зимньої, В.Клачко, О. Леонтьєва, Д. Мазохи, В. Мельман, Н. Симонової, Г. Хамедової, Н. Юдіної, П. Якобсона та ін., мотивацію до вивчення ДМ розглядаємо як складну, багаторівневу неоднорідну систему взаємопов'язаних і підпорядкованих стимулів, мотивів, які спонукають і спрямовують навчальну діяльність студента до поглибленого вивчення ДМ, формують прагнення постійного вдосконалення знань, умінь та навичок з ДМ, пошуку способів здійснення конкретних навчальних завдань, продовження розумової діяльності в нестимулюючих обставинах для досягнення освітньої мети.

Серед визначальних чинників формування навчальної мотивації дослідники (зокрема, (Маркова, 1983; Симонова, 1982) називають освітню систему; особливості організації освітнього процесу, якість викладання; особливості суб'єктів навчальної діяльності; специфіку навчальної дисципліни та міру складності оволодіння нею; важливість предмету для професійної підготовки. Отже, спробуємо окреслити можливості використання ЛСКК як засобу підвищення мотивації до вивчення ДМ крізь призму кожного із зазначених чинників.

1. Освітня система. Протягом тривалого часу в суспільстві (в Україні та за ії межами) формувалися два діаметрально протилежних стереотипи щодо класичних (так званих «мертвих») мов. Прибічники класичної освіти не втомлювалися переконувати, що їх вивчення, викладання та дослідження необхідне, оскільки «для кожної людини, яка претендує на освіченість, особливо для людей, які займаються науками, знання давніх мов якщо не завжди безумовне, то принаймні вкрай необхідне та майже неминуче» (Наук, 1865). Свого часу Л. Толстой зазначав, що «без знання грецької мови немає освіти» (Бирюков, 1921). С. Рачинський ще на початку XX ст. виключення класичних мов з освітніх програм назвав «найбільшим гріхом сучасності перед майбутніми поколіннями» (Рачинский, 1901). Ця проблема активно обговорюється на численних конференціях та методичних семінарах, провідною тезою яких $\epsilon$ те, що в усьому світі давні мови $€$ обов'язковою основою якісної гуманітарної освіти.

Класика не втрачає своєї актуальності та важливості: «коли ми називаємо щось 'класичним', існує усвідомлення чогось тривалого, значущого, що неможливо втратити і що не залежить від будь-яких обставин часу - свого роду безвідносне до часу теперішнє (timeless present), яке сучасне будь-якому іншому теперішньому» (Gadamer, 2004, с. 288). Тому не 
можемо не погодитися з А. Науком, що «час, витрачений на давні мови, ... капітал, який розміщений найбільш безпечним чином та який приносить відсотки протягом усього життя і за будь-яких обставин» (Наук, 1865).

Натомість інша (більша) частина суспільства ставиться вкрай негативно до вивчення та дослідження класичних мов і вважає, що вони не потрібні, а якщо і потрібні, то лише представникам певних спеціальностей. Відомими, зокрема, є іронічні слова С. Маршака: «Зробіть щось надзвичайне. Вивчіть, наприклад... давньогрецьку мову... Для самоповаги. Зробіть щось нелегке і безкорисливе» (Берестов, 1966) (виділення наше - О. Л.-П.).

Відсутність усвідомлення необхідності вивчення класичних мов спричинило, зокрема, ліквідацію спеціальності «Класична філологія» в Київському університеті в період з 1917-1948рр. та 1956-1993 рр. Та й у сучасних освітніх програмах підготовки фахівців різних спеціальностей кількість кредитів, відведених на латинську та/або давньогрецьку мову, з кожним роком катастрофічно зменшується аж до повного їх виключення 3 переліку обов'язкових компонентів чи, бодай, компонентів «вільного вибору студента». Відповідно, у суспільстві укорінюється стереотип про відсутність необхідності вивчати класичні мови навіть у студентів таких, здавалося б, тісно пов'язаних із класичним мовами спеціальностей, як «Філологія», «Право» чи «Історія».

Цей чинник $\epsilon$, на нашу думку, чи не найбільш важливим для формування мотивації студентів до вивчення ДМ. Звичайно, у процесі формування ЛСКК викладач не зможе глобально вплинути на освітню систему в цілому, однак саме від викладача залежить, який стереотип стосовно ДМ сформується у студентів і якою, відповідно, буде мотивація до ії вивчення. У цьому аспекті доречним було б, на наше переконання, у процесі формування ЛСКК з ДМ (особливо їі соціокультурної складової) звертати особливу увагу на свідчення відомих античних авторів про важливість вивчення ДМ, використовувати їхні оригінальні цитати в якості ілюстративного матеріалу, а також на свідчення з давніх та сучасних джерел іншими мовами (наприклад, відомий дидактичний латинський вірш discito graece, написаний ще в XV ст. учителем Еразма Ротердамського Александром Гегієм для пропагування вивчення ДМ, який не втрачав популярності до XIX cт.).

\section{2 Особливості організації освітнього процесу та якість} викладання безпосередньо впливають на формування пізнавальних мотивів, від яких залежить рівень навчальної мотивації студентів. У сучасних лінгводидактичних студіях, присвячених методиці навчання класичних мов, висловлюються різні думки щодо шляхів удосконалення процесу навчання ДМ з метою підвищення навчальної мотивації. Учені наголошують, зокрема, на необхідності виведення викладання ДМ на міждисциплінарний рівень та впровадження різноманітних новітніх прийомів та методів навчання з метою підвищення рівня навчальної мотивації. 
E. Калеранте et al. запорукою ефективності навчання ДМ вважають, зокрема, подолання психологічного бар'єру шляхом залучення культурологічної, країнознавчої складової, виходу за межі власне мовного матеріалу на міждисциплінарний рівень, акцентуючи на тому, що «давньогрецька мова - це зв'язок між минулим, теперішнім та майбутнім; вона відображає наступність на національному рівні, а на глобальному рівні становить вагомий культурний та науковий внесок» (Kalerante, 2010). В. Ціотрас (В.Тбı́́траৎ) наголошує на необхідності впровадження міжкультурного - мультикультурного підходу у процес навчання ДМ (Тбı́траৎ, 2013). Л. Хотелін (L. Houghtalin) пропонує вводити матеріальну культуру в аудиторії, де вивчаються класичні мови, через написи на грецьких вазах та римських монетах, а також через використання карт та планів (Houghtalin, 2018). Т. Мур (T. Moore) обгрунтовує доцільність використання пісень ДМ як ефективного засобу у процесі навчання ДМ (Moore, 2013). Дж. Ірбі (G. Irby) досліджує роль давньогрецької науки як частини давньогрецької культури та особливості використання давньогрецьких наукових текстів у процесі навчання ДМ на початковому та просунутому рівнях (Irby, 2017). У пошуках шляху 'наближення' класичних мов до сучасного студента Дж. Мін доходить висновку, що ефективним засобом є гумор, який робить латинську мову більш доступною, стимулює інтерес і мотивацію студентів там, де їх не вистачає (M in, 2015, с. 18).

Вважаємо, що саме формування ЛСКК дозволяє вивести процес викладання ДМ на міждисциплінарний рівень, дає широке поле діяльності для вдосконалення змісту, прийомів та методів навчання і, відповідно, сприяє формуванню стійкої позитивної мотивації до вивчення ДМ. Втілення вищезазначеного відбувається у процесі формування кожної із взаємопов'язаних субкомпетентностей лСКК з ДМ, серед яких виділяємо (за М. Бушуєвою, Р.Гришковою, Т. Колодько, С. Ніколаєвою та ін.): соціокультурну (передбачає вивчення певного обсягу культурологічних, (лінгво-)країнознавчих, соціокультурних і міжкультурних знань про Давню Грецію, формування здатності користуватися цими знаннями для здійснення успішної професійної діяльності, а також готовності розуміти і приймати еллінську культуру); соціолінгвістичну (охоплює знання правил вербальної та невербальної поведінки, мовних та мовленнєвих засобів спілкування давніх еллінів у різноманітних комунікативних ситуаціях, уміння їх розпізнавати в оригінальних давньогрецьких текстах та адекватно тлумачити); соціальну (знання певних норм і правил спілкування давніх греків, ритуалів і моделей комунікативної поведінки, уміння їх знаходити в текстах, правильно розуміти).

\section{3. Особливості суб'єктів навчальної діяльності.}

Відповідно до навчальних планів (зокрема, Київського національного університету імені Тараса Шевченка), нормативний курс ДМ викладається 
студентам різних спеціальностей у 1-4 семестрах. Саме в початковий період навчання рівень освіти і навчальної мотивації, як зазначає О. Бігич (Бігич, 2004, с. 93), є найвищим. Відтак, перед викладачем постає завдання не лише зберегти цей високий рівень умотивованості, але й підвищити його, беручи до уваги ті чинники, що позитивно чи негативно впливають на іï формування, та вносячи певні корективи у процес навчання. Адже доведено, що «якщо не керувати мотивацією, то може відбутися регрес, зниження її рівня, мотиви втратять дієвість» (Матюхина, 1984, с. 3).

Мотивація нерозривно пов'язана з емоційною сферою суб'єктів навчання, що підкреслюється у працях багатьох дослідників. Зокрема, В. Асєєв зазначає, що мотивація неможлива за межами емоційної сфери людини (Асеев, 1976). П. Сисоєв визначальним фактором вмотивованості вивчати мову, а також загалом ступеня успішності і продуктивності навчання небезпідставно вважає ставлення студента до народу і культури країни, мова якої вивчається (Сысоев, 2004, с. 123). Р. Ґарднер серед основних факторів формування мотивації до вивчення іноземної мови називає, зокрема, інтегративність (Integrativness) (інтерес до іншомовної групи) та ставлення до процесу навчання (Attitudes toward the Learning Situation) (Gardner, 2000).

Інтерес до об'єкта вивчення - один із основних системоутворювальних елементів у теорії і практиці мотивації загалом та один із провідних мотивів навчальної діяльності зокрема (Управлінські, 2004; Степанов, 2003), адже «людина, зацікавлена в чомусь, легко мотивується, не відчуває складнощів у процесі роботи з об'єктом інтересу та не потребує винагороди» (Управлінські, 2004; Шишкоедов, 2009). Відповідно, удосконалення процесу навчання ДМ та підвищення рівня навчальної мотивації студентів ґрунтуються, переважно, на активізації інтересу як «емоційно забарвленої вибіркової спрямованості особистості, що виражається переважно в їі вибірковому ставленні до тих чи інших явищ, предметів чи відповідної діяльності» (Варій, 2009, с. 176). I саме формування ЛСКК з ДМ, на нашу думку, дає найбільш відповідний та вдячний матеріал для підвищення рівня навчальної мотивації шляхом зацікавлення студентів об'єктом вивчення. Зокрема, під час формування лСКК з ДМ у процесі читання та аналізу навчальних текстів доречним $\epsilon$, на нашу думку (з огляду на мотиваційну функцію мистецтва), використання в якості ілюстративного матеріалу творів мистецтва на відповідну тематику, а також різноманітні завдання творчого характеру, що стимулюватиме «художньопізнавальні інтереси й потреби, розвиток навчальних здібностей, творчу організацію особистості та сприятиме формуванню стійкого інтересу» (Музальов, 2012, с. 147-148).

Інша особливість суб'єктів навчання як чинника формування навчальної мотивації була окреслена професором Колумбійського університету Ш. Полоком. Намагаючись зрозуміти причини кризового стану 
класичної філології та демотивованості стосовно вивчення й дослідження класичних мов, науковець робить висновок, що об'єктивною причиною цього $\epsilon$ свого роду замкнене коло: низький рівень оцінки професій, пов'язаних із класичною філологію, сприяє тому, що навчаються класичній філології лише найслабші студенти, а це, своєю чергою, призводить до зниження рівня оцінки цих професій у суспільстві (Pollock, 2011, с. 31). Ускладнюється ситуація ще й тим, що у студентів з високою успішністю переважають пізнавальні та професійні мотиви, внутрішні відносно навчальної діяльності; зі слабкою успішністю - зовнішні, утилітарні мотиви (Бакшаева, 2006, с. 39), які у випадку з класичними мовами не можуть бути домінантними з огляду на об'єктивні обставини. У цьому аспекті мотивація має відігравати особливо важливу роль, адже експериментально доведено, що висока позитивна мотивація може виступати компенсуючим чинником недостатнього рівня спеціальних здібностей, однак високий рівень здібностей не може компенсувати відсутність або низький рівень мотивації (Структура, 2011, с. 6; Мельман, 2009) та ін.

\section{4. Специфіка навчальної дисципліни та міра складності оволодіння}

предметом. У формуванні та розвиткові мотивації важливу роль відіграє зміст навчального матеріалу. І. Зимня зазначає, що специфічною особливістю іноземної мови як навчальної дисципліни є сформоване до неї негативне, суб'єктивне ставлення людей як до складного предмету, що практично не піддається оволодінню в умовах шкільного і вузівського навчання (Зимняя, 1991, с. 36). Особливо актуальною є ця проблема у процесі навчання ДМ: саме граматичні особливості ДМ $є$ однією з головних причин ії несприйняття, що часто ускладнює процес навчання і знижує мотивацію до їі вивчення. Яскравою ілюстрацією цього факту є результати опитування студентів-іноземців, проведеного Е. Калеранте et al.: «Ми зауважили, що вони ставляться до давньогрецької як до важкої i незрозумілої мовної системи форм, яку треба вивчити, щоб 'пройти курс'. Мова, якою 'ніхто не розмовляє', але 'ми повинні вчити'» (Kalerante, 2010, с. 11). Як показує власний досвід викладання класичних мов, таке ставлення $\epsilon$ досить поширеним серед студентів.

Тому вважаємо, що у процесі формування ЛСКК 3 ДМ слід дотримуватися дидактичного принципу «міри складності», сформульованого Л. Занковим (Занков, 1981), який дозволяє оцінити завдання відповідно до пізнавальних можливостей студентів, адже занадто високий рівень складності може стати негативним фактором у процесі формуванні мотивації. 3 іншого боку, навчання має відбуватися на достатньо високому рівні складності, адже якщо завдання не становить для учня проблеми, пізнавальна мотивація не формується (Брушлинский, 1976). Як бачимо, уникнення негативного впливу цього чинника на навчальну мотивацію у процесі формування лСКК $з$ ДМ вимагає від викладача особливої методичної вправності. 3 метою 
підтримання стійкої позитивної мотивації до вивчення ДМ особливу увагу, на нашу думку, слід звертати на формулювання завдань, а також упроваджувати диференційований (за потреби - й індивідуальний) підхід, що дозволить кожному студенту працювати на рівні, який відповідає його здібностям. Доречним вважаємо також застосування наочності у вигляді, наприклад, презентацій у форматі Power Point, що значно полегшує студентам розуміння деяких особливо важких для сприйняття граматичних тем з ДМ.

\section{5. Важливість предмету для професійної підготовки.}

Успішне вивчення всіх дисциплін, зазначених в освітніх програмах підготовки фахівців тієї чи іншої спеціальності, $\epsilon$ необхідною передумовою майбутньої успішної професійної діяльності. Однак, досить часто студенти, не вбачаючи утилітарно-прагматичної перспективи застосування здобутих знань, умінь та навичок, втрачають мотивацію, оскільки не усвідомлюють важливості та необхідності для професійної підготовки вивчення тієї чи іншої дисципліни. Особливо актуальною є ця проблема щодо вивчення класичних (зокрема ДМ) мов. Адже значно нижчий рівень їх практичного застосування порівняно із сучасними європейськими мовами є очевидним. Яскравим підтвердженням цього є опитування, проведене Е. Калеранте et al. (Kalerante, 2010, с. 15): на запитання «який предмет ви хотіли би забрати з навчальної програми?» 82 \% респондентів дали однакову, зумовлену саме утилітарнопрагматичними міркуваннями, відповідь: «Давньогрецьку мову».

Однак існує низка беззаперечних аргументів на користь необхідності вивчення класичних (зокрема ДМ) мов. Найбільш чітко та аргументовано, на нашу думку, їх окреслив ще у XIX ст. А. Наук: найважливішими здобутками людини в результаті вивчення класичних мов (навіть якщо «парадигми і вокабули вилетіли з їі голови і вона не могла вже більше розуміти раніше прочитаних письменників») учений-класик вважає а) краще розуміння власної мови; б) розвиток розумових здібностей; в) більшу зрілість суджень, яка здобувається всебічним управлянням духовних сил; г) моральну енергію, яка виникає з безкорисного служіння вищим інтересам, без будь-якої турботи про їх ринкову цінність у практичному житті (Наук, 1865).

Подібні твердження зустрічаємо також у творах багатьох письменників та науковців наступних століть. Так, Л. Толстой, взявшись за вивчення ДМ, зазначає: «По-перше, я насолоджуюсь; по-друге, переконався, що з усього істинно прекрасного та просто прекрасного, що створило слово людське, я до цього часу нічого не знав; ... по-третє, тому, що я не пишу і писати дріб'язку багатослівного ніколи не буду» (Бирюков, 1921).

А. Наук наголошує, шо «мета інших навчальних предметів зводиться до того, щоб учень знав, а давніх мов - щоб він міг» (Наук, 1865) (виділення наше - О. Л.-П.); а це саме те, чого, на наше переконання, найбільше очікують від висококваліфікованого спеціаліста. Тому вважаємо, що у процесі формування ЛСКК з ДМ слід зосередити увагу на кількох моментах. 
1. Вивчення класичних мов = саморозвиток та самовдосконалення.

У ситуації, коли утилітарно-прагматична та результативна мотивація (яка «відіграє провідну роль у детермінації діяльності» (Варій, 2007, с. 648) не $\epsilon$ чітко окресленою та явно вираженою, а ії рівень $\epsilon$ низьким, на наше переконання, важливо зосереджувати увагу на «процесуально-змістових мотивах - спонукати до дії через зміст і процес діяльності, а не за допомогою зовнішніх чинників», адже в такому випадку інші мотиви (зокрема, утилітарні) «можуть підсилювати мотивацію, але вони не мають безпосереднього стосунку до змісту й процесу діяльності, $\epsilon$ зовнішніми щодо цієї діяльності» (ор. cit., с. 654).

Оскільки мотивація «не тільки детермінує діяльність людини, а й пронизує більшість сфер психічної активності, у тому числі й пізнавальну (це стосується усіх пізнавальних процесів: сприймання, мислення, уяви та пам'яті)» (Столяренко, 2012), «мотивацію навчально-професійної діяльності студентів слід розглядати не тільки як умову ефективного оволодіння знаннями, уміннями та навичками, а й як важливий чинник розвитку особистості майбутнього фахівця» (Мельман, 2009). Відтак, вважаємо, що особливо важливим у процесі формування ЛСКК з ДМ є актуалізація мотиву саморозвитку, наголошення на можливості й необхідності удосконалюватися, адже «сенс діяльності людини не тільки в тому, щоб отримати результат; сенс діяльності полягає і в самій діяльності, у самому процесі діяльності, у тому, щоб виявляти фізичну й інтелектуальну активність» (Варій, 2007, с. 648).

2. Вивчення класичних мов =краще розуміння власної мови.

Апологети важливості вивчення класичних мов акцентують також на тому, що їх вивчення допомагає краще осягнути власну мову. Відомим $є$ вислів Й. В.Гете: «Хто не знайомий з чужою мовою, не знає нічого про свою власну». Ш. Поллок вважає, що «ми вчимося пізнавати світ і пізнавати себе, вивчаючи мову, а вивчення несучасної мови - це найглибший спосіб пізнати власну» (Pollock, 2011, с. 36). За А. Науком, щоб навчитися мислити рідною мовою, слід вивчити давні, адже саме «логічна суворість», яка відрізняє всі давні мови від нових, «відкриває дорогоцінні способи для вправляння в логічному мисленні та в поясненні своїх думок» (Наук, 1865).

3. Вивчення класичних мов = осягнення усього античного інтелектуального спадку.

Вивчення класичних мов «дає доступ до радикально різних форм людської свідомості будь-якому поколінню читачів, ... робить можливою зустріч із невпинною красою та інтелектуальним піднесенням, створеним величезною працею в кілька тисяч років людської свідомості» (Pollock, 2011, с. 36). Греків, як влучно зазначає А. Наук, можна справедливо називати «вчителями людства майже у всіх галузях людського знання» (Наук, 1865). До того ж «заняття з класичних мов відкривають доступ до літературних скарбів двох найбільш освічених народів давнього світу» (ibid.). 
4. Вивчення класичних мов = формування полікультурної, толерантної особистості.

3 огляду на необхідність формування полікультурної особистості на основі міжкультурного підходу до навчання іноземної мови, серед найважливіших цілей навчання іноземної мови, задекларованих Радою Європи, є «ширше і глибше розуміння способів життя і форм мислення інших людей та їх культурного спадку», «взаємне розуміння і терпимість, повага до особистості і культурних відмінностей» (Загальноєвропейські, 2003, с. 14-20). На думку Дж. Ґрубер-Мілера (J. Gruber-M iller), саме вивчення класичних мов може допомогти сучасним студентам, які живуть у мультикультурному світі й повинні навчитися ставати відповідальними громадянами світу, «навчитися розуміти і цінувати різні культурні відносини і, можливо, навчитися співпереживати тим, хто відрізняється від них самих», досліджуючи іншу культуру саме «крізь лінзи греків або римлян», культура яких «'безпечно' віддалена від їхньої власної» (Gruber-M iller, 2008, с. 1-2).

Висновки та перспективи подальших наукових розвідок. Отже, було здійснено спробу окреслити найбільш важливі, на наше переконання, чинники формування навчальної мотивації та визначити роль ЛСКК як засобу підвищення мотивації до вивчення ДМ та класичних мов загалом. Як показують результати дослідження, у процесі формування ЛСКК з ДМ можливо досягнути стійкої позитивної мотивації до вивчення ДМ за умов формування у студентів стійкого позитивного стереотипу щодо класичних мов загалом (та ДМ зокрема) і усвідомлення необхідності їх вивчення та дослідження; виведення процесу викладання ДМ на міждисциплінарний рівень, удосконалення змісту, прийомів та методів навчання під час формування соціокультурної, соціолінгвістичної та соціальної субкомпетентностей ЛскК 3 ДМ шляхом залучення широкого культурологічного тла; підтримання інтересу та позитивної емоційної реакції студентів на об'єкт вивчення; упровадження новітніх технологій та достатньої кількості наочного матеріалу у процес формування лСКК з ДМ для полегшення розуміння особливо важких для сприйняття граматичних тем; застосування диференційованого (та, за потреби, - індивідуального) підходу відповідно до здібностей студентів; активізація процесуально-змістових мотивів у процесі вивчення ДМ; наголошення на важливості вивчення ДМ для загального інтелектуального розвитку, для розширення світогляду та ерудиції шляхом долучення до нетлінних скарбів давньогрецької літератури й мистецтва.

Перспективи подальших наукових студій окресленої проблеми вбачаємо в дослідженні методів, засобів та прийомів підвищення рівня мотивації до вивчення ДМ, а також розробці системи вправ та завдань для формування ЛСКК з ДМ з урахуванням мотиваційної складової. 


\section{ЛITЕРАТУРА}

Асеев, В. Г. (1976). Мотивация поведения и формирования личности. Москва: Мысль (Aseev, V. G. M otivation of behavior and personality formation. M oscow: M ysl).

Бакшаева, Н. А., Вербицкий, А. А. (2006). Психология мотивации студентов. Москва: Логос (Bakshaieva, N. A., Verbitskii, A. A. Psychology of student motivation. M oscow: Logos).

Берестов, В. Д. (1966). Встречи с Маршаком. Юность, 6, 81 (Berestov, V. D. (2016). M eetings with Marshak. Adolescence, 6, 81).

Бігич, О.Б. (2004). Методична освіта майбутнього вчителя іноземної мови початкової школи. Київ: Вид. центр КНлУ (Bihych, О.В.M ethodological education of the future elementary school foreign language teacher. Kyiv: Vyd. centr KNLU).

Брушлинский, А. В., Воловикова, М.И. (1976). О мышлении как прогнозировании. Вопросы психологии, 4, 31-40 (Brushlinskii, A. V., Volovikova, M.I. (1976). About thinking as forecasting. Psychology Issues, 4, 31-40).

Варданян, Ю. В. (1998). Строение и развитие профессиональной компетентности специалиста с высшим образованием (на материале подготовки педагога и психолога) (дисс. ... д-ра пед. наук: 19.00.07). Москва (Vardanian, Yu. V. The structure and development of professional competence of a specialist with higher education) (DSc thesis). M oscow).

Варій, М. Й. (2007). Загальна психологія. Київ: Центр учбової літератури (Varii, М.J. General Psychology. Kyiv).

Варій, М. Й. (2009). Психологія. Київ: Центр учбової літератури (Varii, М. J. Psychology. Kyiv).

Гуревич, Р. С. (2008). Теорія і практика навчання в професійно-технічних закладах. Вінниця: ДОВ «Вінниця» (Hurevych, R. S. Theory and practice of teaching in vocational institutions. Vinnytsia).

Єрохін, С. А. (2011). Концепція професійної мотивації студентів як фактору конкурентності на ринку праці. Науковий юридичний журнал, 1 (1), II, 20-27 (Yerokhin, S. A. (2011). The concept of professional motivation of students as a factor of competitiveness in the labor market, Scientific Law Journal, 1 (1), II, 20-27).

Загальноєвропейські Рекомендації з мовної освіти: вивчення, навчання, очінювання (2003). Київ: Ленвіт (Common European Framework of Reference for Languages: Learning, Teaching, Assessment. Kyiv: Lenvit).

Занков, Л. В. (1981). Обучение и развитие. Москва: Издательство Московского университета (Zankov, L. V. Education and development. M oscow).

Зимняя, И. А. (1991). Психология обучения иностранным языкам в школе. Москва: Просвещение (Zimniaia, I. A. Psychology of teaching foreign languages at school. Moscow).

Маркова, А. К., Матис, Т. А., Орлов,А.Б. (1990). Формирование мотивации учения. Москва: Просвещение (Markova, А. K., Matis, T. А., Orlov, A. B. The formation of learning motivation. M oscow).

Маркова, А. К., Орлов, А. Б., Фридман, Л. М. (1983). Мотивация учения и ее воспитание у школьников. Москва: Педагогика (Markova, A. K., Orlov, A. B., Fridman, L. M. Learning motivation and its education in schoolchildren. M oscow: Pedagogika).

Матюхина, М.В. (1984). Мотивация учения младших школьников. Москва: Педагогика (Matiukhina, M. V. Primary school students learning motivation. M oscow: Pedagogika).

Мельман, В. О. (2009). Психологічні фактори мотивації навчально-професійної діяльності студентів вищих навчальних закладів. Новий колегіум, 6, 56-59. Режим доступу: http://eprints.kname.edu.ua/42980/1/M elman0001.pdf (Melman, V. 0. (2009). Psychological factors of motivation of educational and professional activity of 
higher educational establishments students. New Collegium, 6, 56-59. Retrieved from: http://eprints.kname.edu.ua/42980/1/M elman0001.pdf).

Методика навчання іноземних мов і культур: теорія і практика (2013). Київ: Ленвіт (M ethods of teaching foreign languages and cultures: theory and practice. Kyiv: Lenvit).

Музальов, О.О. (2012). Професійна адаптація особистості в прочесі вивчення предмета «Культурологія» у ВПу. Київ: Педагогічна думка (M uzaliov, 0. 0. Professional adaptation of personality in the process of studying the subject «Cultural Studies» in HVS. Kyiv).

Наук, А. К. (1865). Несколько замечаний о педагогическом значении древних языков. Месяцеслов на 1866 год, 375-394. Режим доступа: http://zaumnik.ru/drevniejazyki-shkole/o-pedagogicheskom-znachenii.html (Nauk, A. K. (1865). A few comments on the pedagogical significance of ancient languages. Months for 1866 , 375-394. Retrieved from: http://zaumnik.ru/drevnie-jazyki-shkole/0pedagogicheskom-znachenii.html).

Рачинский, С. А. (1901). Древние классические языки в школе. Московский сборник, 293298. Режим доступа: http://www.zaumnik.ru/drevnie-jazyki-shkole/rachinskij.html (Rachynskyi, S. A. (1901). Ancient classical languages at school. M oscow collection, 293298. Retrieved from: http://www.zaumnik.ru/drevnie-jazyki-shkole/ rachinskij.html).

Симонова, Н. М. (1982). Экспериментальное исследование структуры мотивации при усвоении иностранного языка в вузе (дис. ... канд. психол. наук: 19.00.07). Москва (Simonova, N. M. An experimental study of the structure of motivation in mastering a foreign language at a university (PhD thesis). M oscow).

Степанов, О.М. (2003). Основи психології i педагогіки. Київ: Академвидав (Stepanov, O. M. Fundamentals of psychology and pedagogy. Kyiv).

Столяренко, О. Б. (2012). Психологія. Київ: Центр учбової літератури. Режим доступу: https:// westudents.com.ua/glavy/80395-4-ponyattya-pro-motivatsyu-ta-mstse-vstruktur-psihki.html (Stoliarenko, O. B. Psychology. Kyiv). Retrieved from: https:// westudents.com.ua/glavy/80395-4-ponyattya-pro-motivatsyu-ta-mstse-vstruktur-psihki.html.

Структура мотивації навчальної діяльності студентів (2011). Харків: XAl (Structure of motivation of students' educational activity. Kharkiv: KhAl).

Сысоев, П. В. (2004). Концепция языкового поликультурного образования (на материале культуроведения США) (дисс. ... д-ра пед. наук: 13.00.02). Москва (Sysoiev, P. V. The concept of linguistic multicultural education (based on the material of cultural studies in the USA) (DSc thesis). M oscow).

Тарнопольський, О. Б. (2019). Методика викладання іноземних мов та їх аспектів у вищій школі. Дніпро: Університет імені Альфреда Нобеля (Tarnopolskyi, O. В. $M$ ethods of teaching foreign languages and their aspects in higher education. Dnipro: Alfred Nobel University).

Управлінські аспекти сочіальної роботи (2004). Київ: МАУП. Режим доступу: https://buklib.net/books/27523/ (M anagement aspects of social work. Kyiv: IAPM). Retrieved from: https://buklib.net/books/27523/.

Бирюков, П. И. (1921). Л.Н.Толстой: Биография. Том ІІ. Берлин, 185-187. Режим доступа: http://zaumnik.ru/drevnie-jazyki-shkole/tolstoj.html (Biriukov, P. I. (1921). L. N. Tolstoy: Biography. V. II. Berlin, 185-187. Retrieved from: http://zaumnik.ru/drevnie-jazyki-shkole/tolstoj.html).

шишкоедов, П.Н. (2009). Общая психология. Москва: Эксмо. Режим доступа: https://psy.wikireading.ru/13012 (Shishkoiedov, P. N. General psychology. Moscow: Eksmo). Retrieved from: https://psy.wikireading.ru/13012. 
A Survey of Beginner's Language Teaching in UK Classics Departments (2018). Ancient Greek Council of University Classical Departments Bulletin, 47, 1-29. Retrieved from: https://cucd.blogs.sas.ac.uk/bulletin/

Gadamer, H.-G. (2004). Truth and M ethod. New York: Continuum.

Gardner R. C. (2000). Correlation, causation, motivation, and second language acquisition. Canadian Psychology, 41, 10-24. Retrieved from: https://pdfs.semanticscholar.org/9907/66883fb85e9ad3785dbd8e4886df477f5958.pdf

Gruber-M iller J. (2008). Teaching Culture in Beginning Greek. Classical Studies. CPL Online, 4.1, 1-10. Retrieved from: https://www.academia.edu /3438690/Teaching_Culture_in_Beginning_Greek.

Houghtalin, L. (2018). Material Culture and the Greek and Latin Classroom. Teaching Classical Languages, 9.1, 39-53.

Irby, G. (2017). Squaring the Circle and Saving the Phenomena: Reading Science in the Greek Language Classroom. Teaching Classical Languages, 8.2, 85-153.

Kalerante, E., Nikolidakis, S., Georgopoulou, E. The teaching of Ancient Greek as a foreign language, for students of immigrant status, at the high school and Lyceum educational levels in Greece. Retrieved from: https://www.lancaster. ac.uk/fass/projects/corpus/UCCTS2010Proceedings/papers/Nikolidakis_et_al.pdf.

Min, J. (2015). Three Categories of Humor in Latin Pedagogy. Teaching Classical Languages, 6.1, 18-36.

M oore, T. (2013). Song in the Greek Classroom. Teaching Classical Languages, 4.2, 66-85. Pollock, Sh. (2011). Crisis in the Classics. Social research, 78.1, 21-48. Retrieved from: http://www.bu.edu/premodern/files/2012/ 08/Cricis-in-the-Classics-Pollock.pdf. Standards for Classical Language Learning (1997). Oxford, OH: American Classical League. Standards for Classical Language Learning (2017). Hamilton, OH: American Classical League.

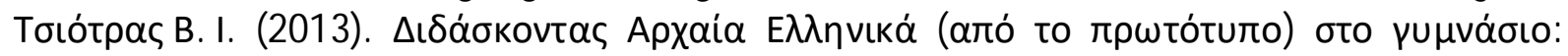

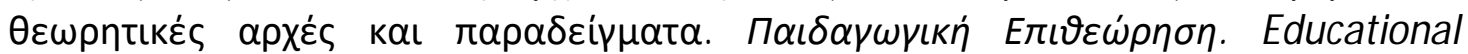
Review, 55, 86-102 (Tsiotras B. I. (2013). Teaching Ancient Greek (from the original) in the high school: theoretical principles and examples. Educational Review, 55, 86-102).

\section{PEЗЮME}

Лазер-Панькив Олеся. Факторы повышения учебной мотивации в процессе формирования лингвосоциокультурной компетентности по древнегреческому языку.

Статья посвящена анализу факторов повышения учебной мотивации в процессе формирования лингвосочиокультурной компетентности по древнегреческому языку. Описываются, в частности, особенности современной образовательной парадигмы и место в ней древнегреческого языка; особенности организации процесса обучения древнегреческому языку, пути и методы повышения качества его преподавания; важнейшие особенности субъектов учебной деятельности, влияющие на уровень мотивации изучения древнегреческого языка; специфика древнегреческого языка и степень сложности овладения ним как факторы возможного негативного влияния на мотивацию; важность древнегреческого языка для профессиональной подготовки. Определяются возможности использования процесса формирования лингвосоциокультурной компетентности как средства повышения мотивации к изучению древнегреческого языка сквозь призму каждого из указанных факторов.

Ключевые слова: учебная мотивация, лингвосочиокультурная компетентность, древнегреческий язык, современная образовательная парадигма, субъекты учебной деятельности. 


\section{SUMMARY}

Lazer-Pankiv Olesia. Factors of Improving Learning Motivation in the Process of Ancient Greek Linguosociocultural Competence Formation.

The article is devoted to the analysis of factors of learning motivation increase in the process of Ancient Greek linguosociocultural competence formation. The peculiarities of the modern educational paradigm and the place of Ancient Greek language in it are outlined, in particular, the causes of the crisis state of modern classical philology and its manifestations in the higher education system are analysed. The features of the Ancient Greek language learning process organization, ways and methods of improving the quality of its teaching are also considered, among which the priority is to bring the Ancient Greek language teaching process to an interdisciplinary level and to introduce new and varied techniques and teaching methods in order to increase the level of learning motivation. Particular attention is paid to the most important features of the subjects of study, which the level of learning Ancient Greek motivation depends on, in particular, the emphasis is placed on the inextricable link of motivation with the emotional sphere and with the interest of the subjects of learning to the object of study. The proposed study also analyses the specificity of ancient Greek (in particular, its grammatical features) and the degree of difficulty in mastering it as an important factor in the possible negative impact on learning Ancient Greek motivation. Particular attention is given to outlining the importance of ancient Greek for the professional training of students as a whole. The utilitarian and pragmatic motives of learning Ancient Greek (as well as other classical languages) are not clearly expressed and defined, that's why it is important to focus on the procedural and content related motives: the important role of learning Ancient Greek for a) self-development and self-improvement; b) a better understanding of their own language; c) comprehension of all ancient intellectual heritage; d) formation of a multicultural, tolerant personality. Possibilities of using the process of linguosociocultural competence formation as a means of increasing Ancient Greek learning motivation are highlighted taking into consideration all the above mentioned factors.

Keywords: learning motivation, linguosociocultural competence, Ancient Greek language, modern educational paradigm, subjects of educational activity.

удк 364-43:364.6

Марина Лехолетова

Київський університет імені Бориса Грінченка ORCID ID 0000-0003-4055-991X

Тетяна Лях

Київський університет імені Бориса Грінченка ORCID ID 0000-0002-8807-0497

DOI 10.24139/2312-5993/2020.02/135-144

\section{ПІДГОТОВКА МАЙБУТНІХ СОЦІАЛЬНИХ ПРАЦІВНИКІВ ДО АДВОКАЦІЙНОї ДІЯЛЬНОСТІ}

Стаття присвячена розгляду сутності представничтва інтересів (адвокації), ролі адвокації в роботі соціальних прачівників. здійснено опис програми підготовки майбутніх соціальних працівників до адвокаційної діяльності. Подано зміст, мету та завдання програми навчальної дисципліни «Технології соціальної адвокації для студентів спеціальності «Соціальна робота».

До ключових тем цієї програми віднесено такі: адвокаційна діяльність соціального працівника; методи соціальної адвокації; організація адвокаційної кампанії; соціальна адвокація як інструмент захисту прав та свобод громадян. 